\title{
ON THE PREDICTABILTTY OF NARRATIVE FISCAL ADJUSTMENTS
}

Pablo Hernández de cos and Enrigue Moral-Benito

Documentos de Trabajo. N. 1516

\section{banco es españa}

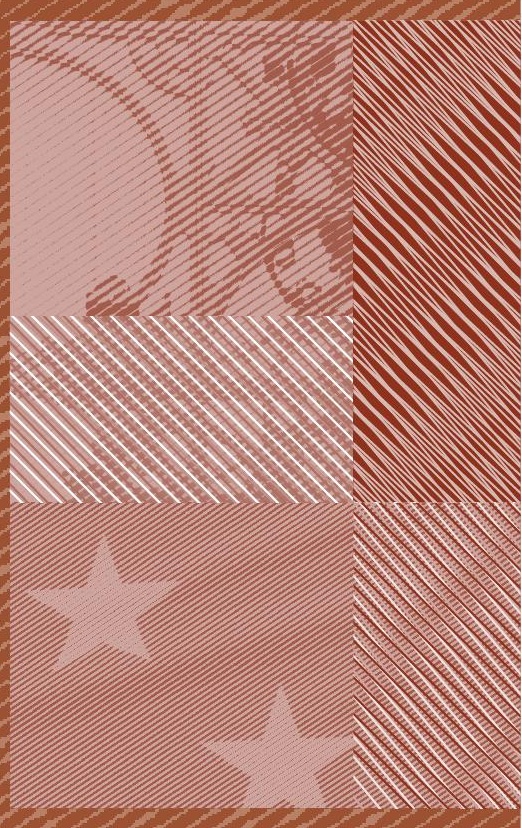


ON THE PREDICTABILITY OF NARRATIVE FISCAL ADJUSTMENTS 
ON THE PREDICTABILITY OF NARRATIVE FISCAL ADJUSTMENTS

Pablo Hernández de Cos and Enrique Moral-Benito ${ }^{(*)}$ BANCO DE ESPAÑA

(*) Corresponding author: Enrique Moral-Benito. Banco de España, Calle Alcala 48, 28014, Madrid, Spain. E-mail: enrique.moral@gmail.com. Phone: (+34)913385687. Fax: (+34)913385486.

Documentos de Trabajo. N. ${ }^{\circ} 1516$ 
The Working Paper Series seeks to disseminate original research in economics and finance. All papers have been anonymously refereed. By publishing these papers, the Banco de España aims to contribute to economic analysis and, in particular, to knowledge of the Spanish economy and its international environment.

The opinions and analyses in the Working Paper Series are the responsibility of the authors and, therefore, do not necessarily coincide with those of the Banco de España or the Eurosystem.

The Banco de España disseminates its main reports and most of its publications via the Internet at the following website: http://www.bde.es.

Reproduction for educational and non-commercial purposes is permitted provided that the source is acknowledged.

C BANCO DE ESPAÑA, Madrid, 2015

ISSN: 1579-8666 (on line) 


\section{Abstract}

In an influential paper, Devries et al. (2011) construct narrative series of tax- and spending-based fiscal adjustments for a panel of OECD countries. In this paper, we find that the adjustments based on spending cuts can be predicted on the basis of past output growth and other macroeconomic variables. Moreover, we illustrate that this source of endogeneity may generate significant differences in the estimated multipliers.

Keywords: fiscal adjustment, fiscal multiplier.

JEL classification: H60, E62. 


\section{Resumen}

En un influyente trabajo, Devries et al. (2011) utilizan el método narrativo para construir una serie de ajustes fiscales exógenos, basados tanto en bajadas de gastos como en subidas de impuestos. El presente trabajo muestra que las consolidaciones fiscales por el lado del gasto no son realmente exógenas, porque están correlacionadas con la evolución pasada de varias series macroeconómicas. Además, se ilustra cómo esta fuente de endogenidad puede tener efectos significativos sobre el multiplicador fiscal estimado.

Palabras clave: consolidación fiscal, multiplicador fiscal.

Códigos JEL: H60, E62. 


\section{Introduction}

Following the seminal contribution by Romer and Romer (2010), Devries et al. (2011) construct series of narrative fiscal adjustments for a panel of 17 OECD countries. Among others, Guajardo et al. (2014), Alesina et al. (2015), and Hernández de Cos and Moral-Benito (2013) exploit these shocks to estimate the macroeconomic consequences of fiscal consolidations. ${ }^{1}$

In order to test the predictability of the narrative-based fiscal adjustments from past macroeconomic fluctuations, we consider Granger causality tests following Cloyne (2013) and probit-based Likelihood Ratio tests in the spirit of Mertens and Ravn (2012). Overall, these tests indicate that narrative adjustments based on spending cuts can indeed be predicted from past realizations of GDP growth, investment, and consumer confidence indicators. ${ }^{2}$ In contrast, the evidence is less clear cut for the adjustments based on tax hikes, which appear to be unpredictable/exogenous.

Simple OLS regressions serve to illustrate that accounting for the predictability of spending-based shocks identified by Devries et al. (2011) may have significant effects on the estimated multipliers due to the procyclicality of these shocks. Therefore, we advocate the use of quasi-experimental approaches for identifying spending-based shocks rather than the narrative record in which the identification of a no-policy-change scenario is always controversial (see Suarez-Serrato and Wingender, 2014; Ramey and Shapiro, 1998).

\section{Data}

The data used in this paper are taken from Alesina et al. (2015). The sample includes annual information for 17 OECD countries from 1978 to $2007 .^{3}$ The episodes of fiscal adjustment identified by Devries et al. (2011) using the narrative approach represent our variable of interest because we aim to investigate its predictability on the basis of past realizations of macroeconomic variables. In the terminology of Alesina et al. (2015), we consider the unexpected adjustments in year $t$ and the past announced adjustments implemented in year $t$. We also consider several macro variables that will be used one at a time to predict the narrative fiscal adjustments. To be more concrete, we use per capita GDP growth, per capita real consumption expenditure growth, gross capital formation per capita growth, consumer and business confidence indicators (in logs), the change in the short-term (three-month) interest rate, and the inflation rate (GDP deflator). Appendix A in Alesina et al. (2015) provides more details on the sources and construction of these variables.

\footnotetext{
${ }^{1}$ Guajardo et al. (2014) consider a VAR framework in which the narrative series are required to be exogenous to contemporaneous (macroeconomic) shocks. Hernández de Cos and Moral-Benito (2013) also allow for feedback from past output fluctuations to current episodes of fiscal consolidation. Finally, Alesina et al. (2015) identify multi-year fiscal plans by exploiting this narrative record and assume that the narrative episodes cannot be predicted from past output growth (or other macroeconomic series).

${ }^{2}$ In a related paper, Jordá and Taylor (2013) show that shifts in fiscal variables identified through the narrative method are predictable using their own past, lagged output growth and past fluctuations in debt dynamics. In this paper, we argue that spending-based narrative adjustments are predictable using exclusively past values of output growth, investment, or consumer confidence indicators.

${ }^{3}$ This dataset is publicly available at http://goo.gl/yuWuBQ. The countries included in the sample are Australia, Austria, Belgium, Canada, Denmark, Finland, France, Germany, Ireland, Italy, Japan, the Netherlands, Portugal, Spain, Sweden, the United Kingdom, and the United States.
} 


\section{Predictability Tests}

Given that the sample contains 30 observations per country, we rely on panel approaches in order to enhance the statistical power for testing our hypothesis. First, we consider a panel version of the VAR Granger causality tests used by Cloyne $(2013)^{4}$ based on the following regression:

$$
e_{i, t}^{N R}=\sum_{k=1}^{K} \gamma_{k} e_{i, t-k}^{N R}+\sum_{k=1}^{K} \beta_{k} \Delta z_{i, t-k}+\eta_{i}+\delta_{t}+\epsilon_{i, t}
$$

where $e_{i, t}^{N R}$ represents the narrative fiscal adjustment identified by Devries at al. (2011) for country $i$ in year $t .^{5}$ Note that we also distinguish between tax- $\left(e_{i, t}^{N R, T X}\right)$ and spending-based $\left(e_{i, t}^{N R, S P}\right)$ adjustments. $\Delta z_{i, t-k}$ refers to the macroeconomic indicator (e.g. per capita GDP growth, investment per capita growth...) whose predictive power we aim to investigate (note that we always consider one macroeconomic variable at a time). Finally, we also include a set of country $\left(\eta_{i}\right)$ and time dummies $\left(\delta_{t}\right)$ to control for unobserved heterogeneity and common shocks. Given this specification, we test the hypothesis that $\Delta z_{i, t}$ does not Granger cause $e_{i, t}^{N R}$, which implies that the $\beta_{k}$ coefficients are jointly zero.

Table 1 reports Granger causality tests for all the macroeconomic variables we analyze. According to the test statistics in Panel A, we conclude that GDP growth and investment do Granger cause the narrative adjustments at the $1 \%$ significance level. Turning to tax-based adjustments in Panel $\mathrm{B}$, we cannot reject the null in any of the seven columns at the $1 \%$ level; we thus conclude that taxbased consolidations identified by the narrative record are not predictable from past macroeconomic fluctuations. Finally, Panel C reports the tests for spending-based adjustments. The main conclusion is that GDP growth, investment, and consumer confidence seem to Granger cause spending-based fiscal adjustments at the $1 \%$ significance level.

Table 1: Granger Causality Tests

\begin{tabular}{|c|c|c|c|c|c|c|c|}
\hline Regressor & $\begin{array}{c}\text { GDP Growth } \\
\text { (1) }\end{array}$ & $\begin{array}{c}\text { Consumption } \\
\text { (2) }\end{array}$ & $\begin{array}{c}\text { Investment } \\
(3)\end{array}$ & $\begin{array}{c}\text { Consumer Confidence } \\
\text { (4) }\end{array}$ & $\begin{array}{c}\text { Business Confidence } \\
\text { (5) }\end{array}$ & $\begin{array}{c}\text { Interest Rate } \\
(6)\end{array}$ & $\begin{array}{l}\text { Inflation } \\
\quad(7)\end{array}$ \\
\hline & \multicolumn{7}{|c|}{ PANEL A: Narrative Fiscal Adjustment $\left(e_{i, t}^{N R}\right)$} \\
\hline Test statistic & $5.871^{* * *}$ & 1.485 & $6.092^{* * *}$ & $3.070^{* *}$ & 1.210 & $2.137^{*}$ & $2.297^{*}$ \\
\hline \multirow[t]{2}{*}{$p$-value } & 0.001 & 0.218 & 0.000 & 0.028 & 0.307 & 0.095 & 0.077 \\
\hline & \multicolumn{7}{|c|}{ PANEL B: Narrative (Tax-Based) Fiscal Adjustment $\left(e_{i, t}^{N R, T X}\right)$} \\
\hline Test statistic & 1.976 & 0.731 & $2.680^{* *}$ & 0.621 & 0.803 & 1.011 & 1.693 \\
\hline \multirow[t]{2}{*}{$p$-value } & 0.117 & 0.534 & 0.047 & 0.602 & 0.493 & 0.388 & 0.168 \\
\hline & \multicolumn{7}{|c|}{ PANEL C: Narrative (Spending-Based) Fiscal Adjustment $\left(e_{i, t}^{N R, S P}\right)$} \\
\hline Test statistic & $5.854^{* * *}$ & $2.190^{*}$ & $6.450^{* * *}$ & $5.048^{* * *}$ & $2.334^{*}$ & $2.303^{*}$ & $2.517^{*}$ \\
\hline$p$-value & 0.001 & 0.089 & 0.000 & 0.002 & 0.074 & 0.077 & 0.058 \\
\hline
\end{tabular}

Dependent variable is the narrative fiscal adjustment (Panel A), tax-based adjustment (Panel B) and spending-based adjustment (Panel C). The macro regressors, included one at a time, are the growth rate of GDP per capita (1), consumption per capita growth (2), investment per capita growth (3), the log of consumer (4) and business confidence (5), the change in the 3M TBill rates (6), and the GDP deflator (7). The null hypothesis is that the coefficients on the distributed lag of each regressor are jointly zero. In all cases we include a set of country and time dummies. Significance levels: *: $10 \% ;{ }^{* *}: 5 \% ;{ }^{* * *}: 1 \%$.

\footnotetext{
${ }^{4}$ Cloyne (2013) considers this approach to validate the exogeneity of the tax policy changes he identifies for the UK based on the narrative record.

${ }^{5}$ In the notation of Alesina et al. (2015), this variable corresponds to $e_{i, t}^{u}+e_{i, t, 0}^{a}$.
} 
A second strategy, based on Mertens and Ravn (2012), consists of transforming the narrative shocks into a 0/1 dummy variable, estimating random-effects probit models with and without past macroeconomic variables among the regressors, and testing the statistical significance of the difference between both estimated likelihood functions. ${ }^{6}$ Table 2 presents the corresponding probit-based Likelihood Ratio tests. In Panel A, $p$-values below 0.01 for investment, consumer confidence, and inflation indicate that these three macro variables do contain information for predicting future episodes of fiscal adjustment. This is so because the fit of the model significantly improves when a distributed lag of any of these variables is included. Turning to tax-based consolidations in Panel B, we can reject the null that the coefficients are zero for investment and inflation at the $1 \%$ level, while we cannot reject the null for GDP growth and the other macro variables at the same significance level. In the case of spending-based adjustments in Panel C, the results confirm our findings in Table 1, GDP growth, investment, and consumer confidence are correlated with future spending-based consolidations identified by Devries et al. (2011).

Table 2: Probit Likelihood Ratio Tests

\begin{tabular}{|c|c|c|c|c|c|c|c|}
\hline Regressor & $\begin{array}{c}\text { GDP Growth } \\
\text { (1) }\end{array}$ & $\begin{array}{c}\text { Consumption } \\
(2)\end{array}$ & $\begin{array}{l}\text { Investment } \\
\text { (3) }\end{array}$ & $\begin{array}{c}\text { Consumer Confidence } \\
\text { (4) }\end{array}$ & $\begin{array}{c}\text { Business Confidence } \\
\text { (5) }\end{array}$ & $\begin{array}{c}\text { Interest Rate } \\
\text { (6) }\end{array}$ & $\begin{array}{c}\text { Inflation } \\
(7)\end{array}$ \\
\hline & \multicolumn{7}{|c|}{ PANEL A: Narrative Fiscal Adjustment $\left(D_{i, t}^{N R}\right)$} \\
\hline Test statistic & $8.758^{* *}$ & $7.657^{*}$ & $18.775^{* * *}$ & $23.167^{* * *}$ & 2.952 & 0.883 & $22.275^{* * *}$ \\
\hline \multirow[t]{2}{*}{$p$-value } & 0.033 & 0.054 & 0.000 & 0.000 & 0.399 & 0.830 & 0.000 \\
\hline & \multicolumn{7}{|c|}{ PANEL B: Narrative (Tax-Based) Fiscal Adjustment $\left(D_{i, t}^{N R, T X}\right)$} \\
\hline Test statistic & 5.023 & 4.441 & $11.408^{* *}$ & $10.424^{* *}$ & 2.119 & 0.788 & $12.606^{* * *}$ \\
\hline \multirow[t]{2}{*}{$p$-value } & 0.170 & 0.218 & 0.010 & 0.015 & 0.548 & 0.852 & 0.006 \\
\hline & \multicolumn{7}{|c|}{ PANEL C: Narrative (Spending-Based) Fiscal Adjustment $\left(D_{i, t}^{N R, S P}\right)$} \\
\hline Test statistic & $13.304^{* * *}$ & 5.610 & $20.791^{* * *}$ & $24.111^{* * *}$ & 5.092 & 3.353 & $11.434^{* *}$ \\
\hline$p$-value & 0.004 & 0.132 & 0.000 & 0.000 & 0.165 & 0.340 & 0.010 \\
\hline
\end{tabular}

Dependent variable is the narrative fiscal adjustment transformed into a dummy variable. In Panel A we consider overall adjustments, in Panel B tax-based adjustments, and in Panel C spending-based adjustments. Each probit includes a distributed lag of the growth rate of GDP per capita (1), consumption per capita growth (2), investment per capita growth (3), the log of consumer (4) and business confidence (5), the change in the $3 \mathrm{M}$ TBill rates (6), and the GDP deflator (7). The null hypothesis is that the coefficients on the distributed lag of each regressor are jointly zero. In all cases we include country-specific effects and a set of time dummies. Significance levels: ${ }^{*}: 10 \% ;{ }^{* *}$ : $5 \%$; ${ }^{* *}: 1 \%$.

In order to examine the sensitivity of our findings above, we consider three alternative exercises for each test reported in Tables 1-2. First, we drop some problematic countries (e.g. the Netherlands and Japan) from our sample one at a time (see Alesina et al., 2015). Second, we consider the unexpected component of the fiscal adjustment, $e_{i, t}^{u}$, as our variable of interest in all of our specifications instead of the overall fiscal shock $e_{i, t}^{N R}$. Third, we consider different lag orders in our specifications. In addition to our baseline choice of three lags we also explored specifications with two, four and five

\footnotetext{
${ }^{6}$ More concretely, we define the dummy variable $D_{i, t}^{N R}$ taking the value 1 if $e_{i, t}^{N R}>0$ and zero otherwise (we also define its tax- $\left(D_{i, t}^{N R, T X}\right)$ and spending-based $\left(D_{i, t}^{N R, S P}\right)$ counterparts). We acknowledge that this approach implies a substantial loss of information as it does not consider the size of the adjustment. We then estimate two randomeffects probits featuring country-specific effects as well as time dummies; one without regressors and the other including lagged values of $\Delta z_{i, t}$. Finally, we consider Likelihood Ratio tests of the null that the variables in the second regression contain no information for forecasting $D_{i, t}^{N R}$.
} 
lags of the macroeconomic variables. In all these cases, results are consistent with our findings. Moreover, we have further considered tests of predictive accuracy based on Diebold and Mariano (1995). In particular, we compare forecasts of the narrative shocks based on two competing models, one exploiting past information on the macroeconomic variables and narrative shocks, and another one exclusively based on lagged values of the narrative shocks. We find that forecasts based on the former are significantly better than that of the latter, which provides further evidence of predictability of the fiscal shocks from past macroeconomic fluctuations. ${ }^{7}$

\section{Implications for the Fiscal Consolidation Multiplier}

Given the claimed exogeneity of narrative fiscal adjustments with respect to macroeconomic conditions, researchers may be tempted to ignore the correlation between past macroeconomic fluctuations and current fiscal adjustments. However, this procedure may result in biased multipliers for the case of spending-based adjustments, which appear to be correlated with past realizations of GDP growth, investment and consumer confidence.

In order to illustrate the potential implications of this concern, we consider a simple OLS regression of output growth $\left(\Delta y_{i, t}\right)$ on a distributed lag of the narrative adjustments $\left(e_{i, t}^{N R}\right)$ and a set of country and time dummies. We also estimate an alternative specification in which lagged investment, GDP growth and consumer confidence are included as control variables. If the narrative adjustments are uncorrelated with these control variables, the estimates should be barely affected by their inclusion in the regression.

Table 3: GDP growth and narrative adjustments with and without control variables

\begin{tabular}{lcccccccc}
\hline \hline & \multicolumn{2}{c}{ Overall Adjustments } & & \multicolumn{2}{c}{ Tax-based Adjustments } & & \multicolumn{2}{c}{ Spending-based Adjustments } \\
\cline { 2 - 3 } & No Controls & Controls & & No Controls & Controls & & No Controls & Controls \\
& $(1)$ & $(2)$ & & $(3)$ & $(4)$ & & $(5)$ & $(6)$ \\
\hline Impact & $-0.27^{* *}$ & $-0.28^{* *}$ & & $-0.54^{* *}$ & $-0.63^{* * *}$ & & $-0.31^{* * *}$ & -0.14 \\
(s.e.) & $(0.11)$ & $(0.11)$ & & $(0.23)$ & $(0.23)$ & & $(0.12)$ & $(0.13)$ \\
Second Year Effect & $-0.52^{* * *}$ & $-0.33^{* * *}$ & & $-1.14^{* * *}$ & $-0.92^{* * *}$ & & $-0.52^{* * *}$ & -0.16 \\
(s.e.) & $(0.17)$ & $(0.12)$ & & $(0.37)$ & $(0.33)$ & & $(0.18)$ & $(0.18)$ \\
\hline
\end{tabular}

The table reports the estimated output effect of a $1 \%$ fiscal adjustment shock identified by the narrative record in the first year (impact) and in the second year. Columns (2), (4) and (6) include GDP, investment and consumer confidence as further control variables while columns (1), (3) and (5) do not. All columns include country-specific effects and a set of time dummies. Significance levels: *: 10\%; **: $5 \% ; * * *: 1 \%$.

Table 3 reports the estimated effects of a $1 \%$ adjustment on output growth under both specifications (with and without controls) and for the three types of fiscal adjustments. Interestingly enough, only in the case of spending-based consolidations the estimated effect substantially differs depending on the inclusion of control variables in the regression. In particular, the negative and significant effect in column (5) loses its statistical significance in the specification with controls reported in column (6). For tax-based adjustments, results are very similar regardless of the inclusion of control

\footnotetext{
${ }^{7}$ For the sake of brevity, we do not report these results in a table, but they are available from the authors upon request.
} 
variables. These illustrative regressions confirm the predictability/endogeneity of spending-based adjustments as opposed to their tax-based counterparts. Moreover, ignoring this source of endogeneity may have important implications for the estimated fiscal consolidation multiplier. In particular, the negative multiplier for spending-based adjustments in column (5) becomes insignificant when controlling for past macroeconomic fluctuations in column (6). This finding points to the prevalence of spending-based consolidations undertaken after periods of loose macroeconomic conditions when cyclical government spending net of transfers is typically lower. ${ }^{8}$

Our interpretation of these results is that spending-based adjustments identified for a panel of countries through the narrative method in Devries et al. (2011) may be endogenous to macroeconomic conditions. We speculate that systematically identifying exogenous spending shocks is controversial due to the challenge in defining a no-policy-change scenario. For the case of taxes, it is more feasible as illustrated by our results and also by Cloyne (2013). Truly exogenous spending shocks can be identified on the basis of quasi-experimental phenomena such as wars (Ramey and Shapiro, 1998) or methodological revisions in Census counts of population (Suarez-Serrato and Wingender, 2014).

\section{Concluding Remarks}

In this paper, we raise the concern that spending-based fiscal adjustments identified by Devries et al. (2011) using the narrative approach can be predicted from past output growth (and also from past investment growth or consumer confidence). Moreover, we illustrate that ignoring this predictability may have significant effects on the estimated multiplier for spending-based adjustments. We conjecture that the difficulties in assessing the no-policy-change scenario in spending cut policies might be at the root of this predictability.

\footnotetext{
${ }^{8}$ If we regress $e_{i, t}^{N R, S P}$ shocks on past macroeconomic indicators (GDP growth, investment and consumer confidence), the joint effect is negative and significant. However, the effect is positive but insignificant for tax-based shocks $\left(e_{i, t}^{N R, T X}\right)$.
} 


\section{References}

[1] Alesina, A., Favero, C., Giavazzi, F. (2015) "The output effect of fiscal consolidation plans." Journal of International Economics, forthcoming.

[2] Cloyne, J. (2013) "Discretionary Tax Changes and the Macroeconomy: New Narrative Evidence from the United Kingdom." The American Economic Review, 103(4), 1507-1528.

[3] DeVries, P., Guajardo, J., Leigh, D., Pescatori, A. (2011) "A new action-based dataset of fiscal consolidation." IMF Working Paper No. 11/128. International Monetary Fund.

[4] Diebold, F., Mariano, R. (1995) "Comparing Predictive Accuracy." Journal of Business and Economic Statistics, 13(3), 134-144.

[5] Guajardo, J., Leigh, D., Pescatori, A. (2014) "Expansionary Austerity? International Evidence." Journal of the European Economic Association, 12(4), 949968.

[6] Hernández de Cos, P., Moral-Benito, E. (2013) "Fiscal Consolidations and Economic Growth." Fiscal Studies, 34(4), 491-515.

[7] Jordá, O., Taylor, A. (2013) "The time for austerity: estimating the average treatment effect of fiscal policy." NBER Working Papers 19414. National Bureau of Economic Research, Inc.

[8] Mertens, K., Ravn, M. (2012) "Empirical Evidence on the Aggregate Effects of Anticipated and Unanticipated US Tax Policy Shocks." American Economic Journal: Economic Policy, 4(2), $145-81$.

[9] Ramey, V., Shapiro, M. (1998) "Costly capital reallocation and the effects of government spending." Carnegie-Rochester Conference Series on Public Policy, 48, 145-194.

[10] Romer, C., Romer, D. (2010) "The Macroeconomic Effects of Tax Changes: Estimation based on a New Measure of Fiscal Shocks." The American Economic Review, 100(3), 763-801.

[11] Suarez-Serrato, J., Wingender, P. (2014) "Estimating local fiscal multipliers." Mimeo, Duke University. 


\title{
BANCO DE ESPAÑA PUBLICATIONS
}

\author{
WORKING PAPERS
}

1401 TERESA SASTRE and FRANCESCA VIANI: Countries' safety and competitiveness, and the estimation of current account misalignments.

1402 FERNANDO BRONER, ALBERTO MARTIN, AITOR ERCE and JAUME VENTURA: Sovereign debt markets in turbulent times: creditor discrimination and crowding-out effects.

1403 JAVIER J. PÉREZ and ROCÍO PRIETO: The structure of sub-national public debt: liquidity vs credit risks.

1404 BING XU, ADRIAN VAN RIXTEL and MICHIEL VAN LEUVENSTEIJN: Measuring bank competition in China: a comparison of new versus conventional approaches applied to loan markets.

1405 MIGUEL GARCÍA-POSADA and JUAN S. MORA-SANGUINETTI: Entrepreneurship and enforcement institutions: disaggregated evidence for Spain.

1406 MARIYA HAKE, FERNANDO LÓPEZ-VICENTE and LUIS MOLINA: Do the drivers of loan dollarisation differ between CESEE and Latin America? A meta-analysis.

1407 JOSÉ MANUEL MONTERO and ALBERTO URTASUN: Price-cost mark-ups in the Spanish economy: a microeconomic perspective.

1408 FRANCISCO DE CASTRO, FRANCISCO MARTÍ, ANTONIO MONTESINOS, JAVIER J. PÉREZ and A. JESÚS SÁNCHEZ-FUENTES: Fiscal policies in Spain: main stylised facts revisited.

1409 MARÍA J. NIETO: Third-country relations in the Directive establishing a framework for the recovery and resolution of credit institutions.

1410 ÓSCAR ARCE and SERGIO MAYORDOMO: Short-sale constraints and financial stability: evidence from the Spanish market.

1411 RODOLFO G. CAMPOS and ILIANA REGGIO: Consumption in the shadow of unemployment.

1412 PAUL EHLING and DAVID HAUSHALTER: When does cash matter? Evidence for private firms.

1413 PAUL EHLING and CHRISTIAN HEYERDAHL-LARSEN: Correlations.

1414 IRINA BALTEANU and AITOR ERCE: Banking crises and sovereign defaults in emerging markets: exploring the links.

1415 ÁNGEL ESTRADA, DANIEL GARROTE, EVA VALDEOLIVAS and JAVIER VALLÉS: Household debt and uncertainty: private consumption after the Great Recession.

1416 DIEGO J. PEDREGAL, JAVIER J. PÉREZ and A. JESÚS SÁNCHEZ-FUENTES: A toolkit to strengthen government budget surveillance.

1417 J. IGNACIO CONDE-RUIZ, and CLARA I. GONZÁLEZ: From Bismarck to Beveridge: the other pension reform in Spain.

1418 PABLO HERNÁNDEZ DE COS, GERRIT B. KOESTER, ENRIQUE MORAL-BENITO and CHRISTIANE NICKEL: Signalling fiscal stress in the euro area: a country-specific early warning system.

1419 MIGUEL ALMUNIA and DAVID LÓPEZ-RODRÍGUEZ: Heterogeneous responses to effective tax enforcement: evidence from Spanish firms.

1420 ALFONSO R. SÁNCHEZ: The automatic adjustment of pension expenditures in Spain: an evaluation of the 2013 pension reform

1421 JAVIER ANDRÉS, ÓSCAR ARCE and CARLOS THOMAS: Structural reforms in a debt overhang.

1422 LAURA HOSPIDO and ENRIQUE MORAL-BENITO: The public sector wage premium in Spain: evidence from longitudinal administrative data.

1423 MARÍA DOLORES GADEA-RIVAS, ANA GÓMEZ-LOSCOS and GABRIEL PÉREZ-QUIRÓS: The Two Greatest. Great Recession vs. Great Moderation.

1424 ENRIQUE MORAL-BENITO and OLIVER ROEHN: The impact of financial (de)regulation on current account balances.

1425 MAXIMO CAMACHO and JAIME MARTINEZ-MARTIN: Real-time forecasting US GDP from small-scale factor models.

1426 ALFREDO MARTÍN OLIVER, SONIA RUANO PARDO and VICENTE SALAS FUMÁS: Productivity and welfare: an application to the Spanish banking industry.

1427 JAVIER ANDRÉS and PABLO BURRIEL: Inflation dynamics in a model with firm entry and (some) heterogeneity.

1428 CARMEN BROTO and LUIS MOLINA: Sovereign ratings and their asymmetric response to fundamentals.

1429 JUAN ÁNGEL GARCÍA and RICARDO GIMENO: Flight-to-liquidity flows in the euro area sovereign debt crisis.

1430 ANDRĖ LEMELIN, FERNANDO RUBIERA-MOROLLÓN and ANA GÓMEZ-LOSCOS: Measuring urban agglomeration. A refoundation of the mean city-population size index.

1431 LUIS DIEEZ-CATALÁN and ERNESTO VILLANUEVA: Contract staggering and unemployment during the Great Recession: evidence from Spain. 
1501 LAURA HOSPIDO and EVA MORENO-GALBIS: The Spanish productivity puzzle in the Great Recession.

1502 LAURA HOSPIDO, ERNESTO VILLANUEVA and GEMA ZAMARRO: Finance for all: the impact of financial literacy training in compulsory secondary education in Spain.

1503 MARIO IZQUIERDO, JUAN F. JIMENO and AITOR LACUESTA: Spain: from immigration to emigration?

1504 PAULINO FONT, MARIO IZQUIERDO and SERGIO PUENTE: Real wage responsiveness to unemployment in Spain: asymmetries along the business cycle.

1505 JUAN S. MORA-SANGUINETTI and NUNO GAROUPA: Litigation in Spain 2001-2010: Exploring the market for legal services.

1506 ANDRES ALMAZAN, ALFREDO MARTÍN-OLIVER and JESÚS SAURINA: Securitization and banks' capital structure.

1507 JUAN F. JIMENO, MARTA MARTÍNEZ-MATUTE and JUAN S. MORA-SANGUINEITI: Employment protection legislation and labor court activity in Spain.

1508 JOAN PAREDES, JAVIER J. PÉREZ and GABRIEL PEREZ-QUIRÓS: Fiscal targets. A guide to forecasters?

1509 MAXIMO CAMACHO and JAIME MARTINEZ-MARTIN: Monitoring the world business cycle.

1510 JAVIER MENCÍA and ENRIQUE SENTANA: Volatility-related exchange traded assets: an econometric investigation.

1511 PATRICIA GÓMEZ-GONZÁLEZ: Financial innovation in sovereign borrowing and public provision of liquidity.

1512 MIGUEL GARCÍA-POSADA and MARCOS MARCHETTI: The bank lending channel of unconventional monetary policy: the impact of the VLTROs on credit supply in Spain.

1513 JUAN DE LUCIO, RAÚL MÍNGUEZ, ASIER MINONDO and FRANCISCO REQUENA: Networks and the dynamics of firms' export portfolio.

1514 ALFREDO IBÁÑEZ: Default near-the-default-point: the value of and the distance to default.

1515 IVÁN KATARYNIUK and JAVIER VALLÉS: Fiscal consolidation after the Great Recession: the role of composition.

1516 PABLO HERNÁNDEZ DE COS and ENRIQUE MORAL-BENITO: On the predictability of narrative fiscal adjustments.

\section{BANCODEESPAÑA}

Eurosistema
Unidad de Servicios Auxiliares

Alcalá, 48 - 28014 Madrid

E-mail: publicaciones@bde.es www.bde.es 